\title{
DEVELOPMENT STRATEGIES FOR REGIONAL TRANSPORT AND LOGISTICS SYSTEMS IN UKRAINE
}

\section{Dugienko N.O., Stepanov S.U.}

Zaporizhzhia National University

Ukraine, 69600, Zaporizhzhia, Zhukovsky str., 66

dugienkonata@ukr.net, savastepanov65@i.ua

\section{ORCID 0000-0002-4551-5548, 0000-0003-4743-962X}

Key words:

transport and logistics system, logistics, infrastructure, strategy, tools.
The authors consider the gradual process of the development strategy of transportlogistic system of the region: which includes the analysis and assessment of the level of transport and logistic system of the region, the choice of the logistics of the mission, goals, strategy. One of the main logistical problems of development of regions of Ukraine has been defined; that does not allow using enough logistic opportunities of the regions. It is noted that the formation of integrated transport and logistics systems is an important factor in the economic development of the regions of Ukraine. The definition of "transport and logistics system" has been proposed. Tools for the implementation of transport and logistics strategy have been given. Types of regional logistics development strategies have been proposed. The urgency of regional logistics development has been noted, because of regional and interregional logistics systems solve many problems and ways to overcome them have been found. The definition of "logistics mission" has been proposed. The main components of the logistics mission have been considered. The components of the assessment of the logistics potential and the content of each component have been analysed. The types of regional transport and logistics development strategies are proposed. The content of each of the proposed regional transport and logistics strategies has been analysed. The main tasks for achieving the goals of sustainable development of the regional transport and logistics system have been presented. The level of logistics development of Ukrainian regions has been analysed, and the regions of Ukraine with the large logistics capacity to implement the targets of the development of regional transport-logistic system in the mission have been determined.

\section{СТРАТЕГІЇ РОЗВИТКУ РЕГІОНАЛЬНИХ ТРАНСПОРТНО-ЛОГІСТИЧНИХ СИСТЕМ УКРАЇНИ} Дугієнко Н.О., Степанов С.Ю.

\author{
Запорізький національний університет \\ Україна, 69600, м. Запоріжжя, вул. Жуковського, 66
}

\section{Ключові слова:}

транспортно-логістична система, логістика, інфраструктура, стратегія, інструменти.
Розглянуто поетапний процес розробки стратегії розвитку транспортнологістичної системи регіону, до якого входять: аналіз та оцінка рівня транспортно-логістичної системи регіону, вибір логістичної місії, цілей, стратегії. Визначено одну з головних логістичних проблем розвитку регіонів України, що не дозволяє достатньо використовувати логістичні можливості регіонів. Зазначено, що формування інтегрованих транспортно-логістичних систем $\epsilon$ важливим фактором економічного розвитку регіонів України. Розглянуто поняття «транспортно-логістична система». Охарактеризовано інструменти для реалізації транспортно-логістичної стратегії. Зазначено актуальність розвитку логістики регіонів, адже саме завдяки регіональним та міжрегіональним логістичним системам вирішується безліч проблем та знаходяться шляхи їх подолання. Визначено поняття «логістична місія» та основні складові логістичної місії. Проаналізовано складові оцінки логістичного потенціалу та зміст кожної складової. Запропоновано види регіональних транспортно-логістичних стратегій розвитку. Проаналізовано зміст стратегії лідерства, глобалізації та міжрегіональної інтеграції. Наведено основний зміст стратегії інтенсифікації економічних потоків. Розглянуто стратегію нарощення логістичного потенціалу. Визначено головні проблеми та цілі стратегії нарощення логістичного потенціалу, а також головну мету стратегії формування регіональної логістичної системи. Наведено основні шляхи мінімізації витрат під час реалізації стратегії формування регіональної логістичної системи Наведено основні завдання для досягнення цілей сталого розвитку регіональної транспортнологістичної системи. Проаналізовано рівень логістичного розвитку регіонів України та визначено регіони України, що мають великий логістичний потенціал для реалізації цільових орієнтирів розвитку регіональної транспортно-логістичної системи в межах місії. 


\section{Statement of the problem}

In modern conditions, the logistics potential for regional development is not used rationally. Unfortunately, the modern specialization of the regions of Ukraine is unproductive. Also, there is no balanced mechanism for the management of economic flows.

As world experience shows, the most effective direction of development of transport sector of Ukraine can be realized through the development of transport-logistics system, which provides interaction between all participants in the transport and distribution process in the organizational-economic, technical, technological and informational aspects during the movement of cargo flows to the end user, and also allows you to take a competitive position in the international markets of transport and logistics services.

Therefore, the uncertainty of the regional leadership about the transport and logistics development strategy requires the introduction of new approaches to managing the regional economy on the principles of logistics.

\section{Analysis of recent studies and publications}

Such scientists as V. Smirichinsky [5], O. Nosov, E. Belyakova, V. Sergeev, R. Larina, T. Prokofiev, and I. Rabadanova studied the problems of integrated management of regional development using a logistic approach to management. Such scientists as V. Braginsky [1], S. Gerasimchuk [2], I. Koblyanskaya [3], V. Yudenko [4], V. Zakharchenko, M. Dovba, O. Kutakha, L. Ponomarenko, M. Grigorak, E. Krikavsky devoted scientific works to the formation and functioning of transport and logistics infrastructure in Ukraine. The general problems of creating transport and logistics systems have been thoroughly analysed by such foreign scientists as D. Bauersox, D. Kloss, D. Lambert, S. Langley, K. Melzer, I. Schneider, and others. However, the issues of sustainable development of the regional transport and logistics system do not lose their relevance and require further research.

\section{Objectives of the article}

The purpose of this article is to define the process of developing a transport and logistics strategy of the region, and identify types of transportation and logistics development strategies in the region.

\section{The main material of the research}

The status of Ukraine as a state that can be not only a strategic partner for other countries, due to its territorial location and the availability of certain natural resources and agricultural potential, but also to be able to compete with these countries in many industries, is the main goal set by all state authorities, local governments and individual enterprises in the region.

Considering the economy of the region as a subsystem in relation to the economy of the country as a whole, it can be noted that in this aspect, the activity of the region takes the form of appropriate activities to transform the economic space and economic conditions, that is, the business climate. Undoubtedly, it is important to develop not only an annual, but also a long-term (strategic) program for the development of a specific territory.

One of the main logistical problems of the development of the regions of Ukraine is inefficient management of the transport and logistics system, which does not allow sufficient use of the logistics capabilities of the regions. Such management does not take into account the potential of the region in both resource and economic terms. In addition, logistics opportunities are not used in the regions, and inefficient management of material, financial and information flows has led to an imbalance in the regions. That is why the development of a balanced transport and logistics strategy of the regions of the state is extremely necessary for the further full use of the economic potential of each region of Ukraine. Therefore, one of the important factors of economic growth is the formation of integrated transport and logistics systems covering the regions of Ukraine.

Note that the transport and logistics system is an integrated set of subjects of transport and logistics activities and objects of transport and logistics infrastructure that interact with each other in order to optimize the movement of cargo flows "from door to door" with minimal costs on the most favourable terms. It should be added that the transport and logistics system, like any other system, consists of specific subsystems and elements [1].

The process of developing the transport and logistics strategy of the region is an extremely complex process. The algorithm of this process is as follows:

1. Analysis and assessment of the level of development of the transport and logistics system.

2. The choice of the logistics of the mission.

3 . The choice of the logistic objectives.

4. Choice of transport and logistics strategy.

5. Strategy implementation.

6. Monitoring the implementation of the strategy.

7. Assess compliance of plans with a specific strategy before results.

8. Generalization or synthesis of analysis results and justification of management decisions.

The first step in this development process and the choice of logistics strategy in the region, and selection of strategic priorities of development of the regional logistics system is the analysis and assessment of the level of development of the region. Analysis and assessment of the level of development of the regional logistics system are carried out in two directions: analysis and assessment of the logistics potential of the region (Table 1), analysis and evaluation of the logistics of the region's economy (Table 2). 
Table 1- Level of logistics potential of Ukrainian regions

\begin{tabular}{|l|l|}
\hline \multicolumn{1}{|c|}{ High } & \multicolumn{1}{c|}{ Low } \\
\hline $\begin{array}{l}\text { Luhansk region, Zaporizhzhia region, Kharkiv region, } \\
\text { Donetsk region, Dnipropetrovsk region, Odessa } \\
\text { region. }\end{array}$ & $\begin{array}{l}\text { Vinnytsia region, Rivne, Zhytomyr region, Khmelnytsky } \\
\text { region, Ternopil region, Ivano-Frankivsk region, Cherkasy } \\
\text { region, Kirovograd region, Mykolaiv region, Kherson region, } \\
\text { Chernivtsi region, Chernihiv region, Volyn region, Lviv } \\
\text { region, Transcarpathian region, Sumy region, Kiev region, } \\
\text { Crimea, Poltava region. }\end{array}$ \\
\hline
\end{tabular}

Source: built on data [2]

Table 2 - Level of logistics of the region's economy

\begin{tabular}{|l|l|}
\hline \multicolumn{1}{|c|}{ High } & \multicolumn{1}{|c|}{ Low } \\
\hline $\begin{array}{l}\text { Volyn region, Lviv region Transcarpathian region, } \\
\text { Sumy region, Kiev region, Crimea, Poltava region, } \\
\begin{array}{l}\text { Donetsk region, Dnipropetrovsk region, Odessa } \\
\text { region. }\end{array}\end{array}$ & $\begin{array}{l}\text { Vinnytsia region, Rivne region, Zhytomyr region, } \\
\text { Khelnytsky region, Ternopil region, Ivano-Frankivsk } \\
\text { region, Cherkasy region, Kirovograd region, Mykolaiv } \\
\text { region, Kherson region, Chernivtsi region, Chernihiv region.. }\end{array}$ \\
\hline
\end{tabular}

Source: built on data [2]

Indicators of analytical research (Table 1 and Table 2) demonstrate a different level of development of local transport and logistics systems, where the regions of the country differ significantly both in terms of logistics potential and the level of logistics of their economy. This requires the introduction of differentiated approaches to the choice of logistics strategy and strategic values for the development of regional logistics strategy.

Unfortunately, the regions of Ukraine do not fully use their opportunities and do not attract the necessary investment volumes, although they have an extremely favourable geopolitical location and a significant level of logistics potential. Therefore, it is extremely important to develop logistics strategies for the development of regions depending on the existing logistics potential and the level of logistics of their economy.

The second stage is the choice of logistics mission. Note that the logistics mission is to improve the efficiency of the regional logistics system to ensure a high quality of life for the population of the region, which requires finding and maintaining an optimal balance of interaction between all elements of the regional logistics system. The logistics potential of the region reflects the possibility of implementing targets for the development of the regional logistics system within the mission, which is a strategic factor in the conditions of increasing competition.

At each level of management, the mission must be transformed into the specific logistics objectives of the regional logistics system. The choice of logistics goals should be carried out according to clearly defined evaluation criteria, namely: the level of logistics potential and the level of logistics of the region's economy.

The logistics potential of the region is the ability of the regional system to provide optimal parameters of economic flows in space and time, which are formed as a result of the application of logistics management methods. The criterion of optimality is the minimum public expenditure on managing economic flows.

The logistics potential can be considered as the result of integration of components of the regional system of commodity movement, which should be quantified. This, in turn, determines the need to study the logistics potential of the region from the standpoint of its structural and functional content.
The components of the assessment of the logistics potential of the region are specialization, natural resources, geopolitical and infrastructure [3].

If we consider the content of each component of the logistics potential of the region, then to assess:

- specialization the region's specialization coefficient is determined;

- natural resource component determines the total resource potential per capita and unit of territory;

- geopolitical component determines the indices of proximity to the capital, the country's borders, ports, international airports and transport corridors;

- infrastructure component determines the number of railways and road directions in the region, the density of Railways and public paved roads, the proportion of paved roads, the number of wholesale and retail enterprises, the total area of their own warehouses of wholesale trade enterprises, as well as the overall level of mobile coverage of the territories of the region and the number of Internet providers in the region.

In order to achieve the goals of sustainable development of the regional transport and logistics system, the following tasks must be fulfilled:

- formation and development of the optimal structure of the economic complex of the region;

- rational use of available natural resources and maintenance of ecological safety of the region;

- development of transport, industrial and social infrastructure;

- full satisfaction of the needs of the population in highquality material goods and services [2].

The next stage is the choice of transport and logistics strategy. The strategy provides for improving the use of the region's logistics development potential, establishing a mechanism for managing transport, financial and information flows in the region, as well as ensuring effective interaction with other regions. Scientists distinguish types of transport and logistics strategies depending on the level of development of the regional logistics system (Fig. 1). 


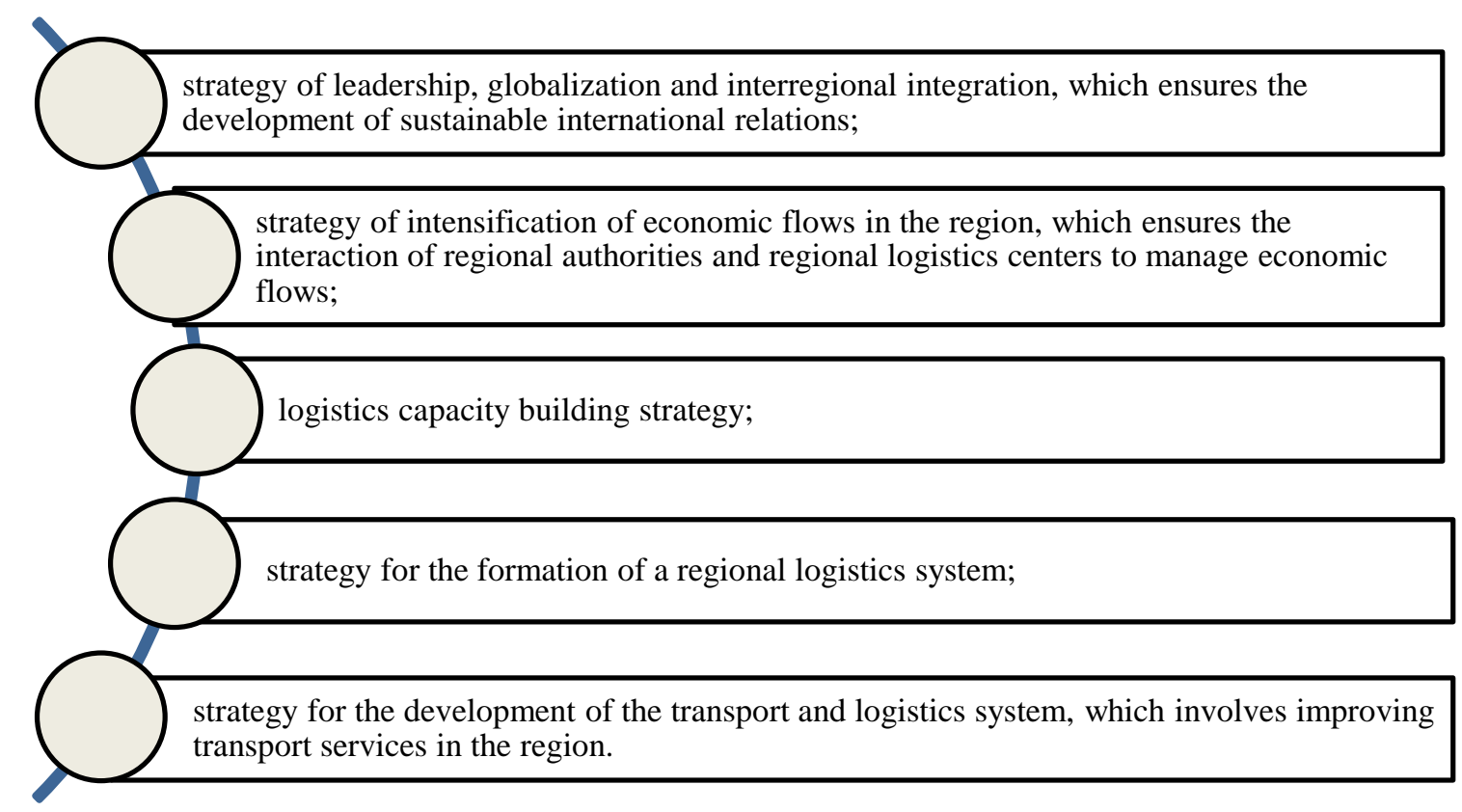

Fig. 1. Types of transport and logistics strategies

The strategy of leadership, globalization and interregional integration should be used by regions that have a sufficiently high level of logistics potential and a high level of economic logistics. This strategy is aimed at developing inter-regional and inter-sectoral economic relations. The main idea of this strategy is to create a unified system of relationships between the participants of an integrated logistics system by coordinating the interests of their elements. It provides for the formation of stable trade and economic relations between individual countries or groups of countries on the basis of the international division of labour. The strategy also aims to achieve an increase in the efficiency of the supply chain, when all its participants, working together and together, benefit from long-term cooperation. The implementation of the integration strategy makes it possible to cover and combine into a single process production, service, commercial and other activities related to the planning and management of flow processes that occur in the regional transport and logistics system.

The strategy of intensification of economic flows involves intensifying the efforts of regional authorities and regional logistics centres to streamline the system of movement of both internal regional and interregional economic flows and effective management of them. Behind this strategy, it is necessary to intensify efforts to streamline the system of movement of goods flows, organize their concentration and transformation in regional logistics centres (terminals), effectively manage inventory and order management systems, and ensure the maintenance of logistics infrastructure facilities.

Rational organization of transport flows provides for the development of both ways of communication (road, rail) and complexes for cargo handling (railway stations, terminals, access roads, repair enterprises, services. Any region can get many advantages from attracting transit cargo flows and organizing their effective passage, in particular, more complete use of communication routes, increasing the volume of cargo transshipment, increasing payments to budgets of all levels, the possibility of attracting investors, creating new jobs.

It is necessary to pay attention to the fact that in the system of intensification of economic flows of the region, a special place is occupied by the use of geoinformation systems, which make it possible to combine a model image of the territory (electronic display of maps, schemes) with tabular information (various statistics, lists, economic indicators, etc.) [4].

Information flows must be present at all stages of the supply chain: demand, order, inventory status, production, delivery, control of the order fulfilment. This means that information flows from all parts of the logistics chain (suppliers, manufacturers, distributors, carriers, logistics operators, etc.) must be integrated.

Therefore, the use of information systems allows for the centralization of all work on information technology within the supply chain as a whole. Centralized collection and processing of information, providing it to all participants provides horizontal links between them. According to this, the effect of integration of all participants in the regional logistics system into a single whole is achieved.

The strategy of increasing the logistics potential provides for the development of the logistics infrastructure of the regions, the formation of an optimal structure of the region's economy, to ensure its specialization and the introduction of modern logistics management technologies. The logistics potential of the region should be aimed at improving the efficiency of customer service due to the high quality of logistics services, bringing them closer to world standards, and the introduction of modern logistics technologies for managing the regional logistics system.

As part of this strategy, each of the regions specializes in separate economic activities. These regions are characterized by a low technological way of production, which requires first of all a change in the region's specialization in the direction of development of 
knowledge-intensive activities. At the same time, one of the main problems in the development of regions in this group is the slowdown in production growth, underdevelopment of technology markets, intangible assets, lack of a full-fledged monitoring system, regional management, imperfection of the intra-industry structure of production, and so on. Therefore, this leads to the need to change the sectoral structure of the region's economy.

Transit of territories by rail, road, water and air transport can become one of the main sources of income of the regions of the state. This, in turn, will ensure the passage of transport flows of the regional logistics system. Due to the operation of infrastructure facilities, the annual profit will grow, as well as the economic activity of the surrounding territories will significantly revive. At the same time, there will be a need for the services of the construction industry for the improvement of major highways. The implementation of the region's transit capabilities and transport infrastructure will increase the profitability of many economic activities and ensure the passage of transport flows.

According to this strategy, a single logistics chain is formed, containing five areas of efficiency:

- communication with suppliers;

- communication with consumers;

- technological processes within the logistics system;

- logistics processes between elements of the regional logistics system;

- logistics links between enterprises in the logistics chain [4].

This strategy has an important place in the regional logistics system. The formation of a logistics system within the framework of this strategy leads to overcoming the crisis phenomena in the economy of the region that arise at each stage of development, creating the necessary infrastructure, developing interregional, inter-sectoral and international relations, as well as a comprehensive rational use of financial, material, and information flows.

Creation of prerequisites for development of transport and logistics system and ensuring logistical economy of the region by formation of a system of management of material and information flows is the main objective of the strategy of the formation of a regional logistics system for the region.
Logistics centres should be the Foundation for the formation of the logistics system. Logistics centres have the ability to reduce overall logistics costs, receive appropriate discounts and a relative reduction in specific transport costs due to the availability of sufficient material and technical base, experience in organizing commodity supply, as well as a qualified commercial apparatus.

It is worth noting that in the system of implementation of this strategy, much attention is paid to measures related to cost minimization. Cost minimization is achieved by ensuring the greatest efficiency of resource flows, namely: the elimination of production waste, minimizing the time of execution of orders, the rejection of the formation of reserve reserves, and so on.

Measures to implement this strategy are the choice of simple operations, improving the flow of information and materials, the use of standard procedures and materials, the rejection of sequentially performed operations in parallel, the ensuring uninterrupted material flow [5].

The pre-selected evaluation criteria allow you to monitor the implementation of the strategy. Constant or periodic comparison of the specified characteristics and parameters of the current values of these parameters makes it possible to assess the level of order fulfilment, distribution, production, and so on. The control allows you to track and evaluate how effectively the tasks are implemented, the main of which is to optimize the flows of the regional logistics system.

\section{Conclusions}

The proposed strategies for the development of the regional transport and logistics system make it possible to form the logistics potential of the region, to ensure a high level of logistics of the region's economy. As a result, this approach will contribute to the development of the regional transport and logistics system as a whole. The introduction of regional transport and logistics strategies makes it possible to expand the specialization of the country and regions as a whole, to improve the process of customer service; to increase sales markets for goods and services; to reduce the cost of sales and delivery of goods; to improve the logistics infrastructure of the region, to ensure the formation of sustainable development of the region.

\section{References}

1. Brahinskyi, V.V. (2010). Rozvytok transportno-lohistychnoi systemy yak forma realizatsii tranzytnoho potentsialu Ukrainy [Development of transport and logistics system as a form of realization of transit potential of Ukraine]. Retrieved from http://academy.gov.ua/ej/ej14/txts/Braginskiy.pdf

2. Herasymchuk, Z.V. (2010). Stratehichni priorytety rozvytku rehionalnykh lohistychnykh system [Strategic priorities for the development of regional logistics systems]. Retrieved from http://ena.lp.edu.ua: 8080/bitstream/ntb/11985/1/97.pdf

3. Koblianska, I.I. (2015). Lohistychnyi potentsial rehionu: sutnist i metodychnyi pidkhid shchodo yoho otsiniuvannia [Logistics potential of the region: the essence and methodological approach to its assessment]. Retrieved from http://essuir.sumdu.edu.ua/handle/123456789/43253

4. Yudenko, V.V. (2015). Lohistychni stratehii pidpryiemstva v umovakh staloho rozvytku [Logistics strategies of the enterprise in terms of sustainable development]. Retrieved from http://ir.nmu.org.ua/jspui/bitstream/ 123456789/148112/1/42-44.pdf

5. Smyrychynskyi, V.V. (2004). Lohistychnyi menedzhment derzhavnykh zakupivel. Teoretyko-pravovyi ta metodolohichnyi aspect [Logistics management of public procurement]. Ternopil: Kart-blansh [in Ukrainian] 